\title{
Reflections of a Teacher Educator of Religion Education: Informing and Transforming Practice
}

\section{Janet Jarvis}

\section{Abstract}

The voice of the Religion Education teacher can either entrench religious discrimination or embrace religious diversity and promote intra- and interreligious dialogue. Set against the background of political and curriculum change in South Africa, this article traces the trajectory that I have pursued as a teacher of Religion Education at secondary schools, at a former college of education and in my current position as a teacher educator at a university in South Africa. This personal history self-study provides an account of the paradigm shifts I have undergone from what I call religious identity paralysis, to religious identity paradox, to religious identity flexibility, and finally to my current position of ongoing religious identity transformation. In doing so, I mirror something of my journey from a mono-religious approach to teaching Religion Education to that of a multi-religious approach, and more recently, to the emergence of an empathetic-reflective-dialogical approach. I use the lens of the dialogical self and religious identity capital to interpret my story. The possibility exists that my understanding of how and why I made changes to my approach to Religion Education can inform my practice as I encourage my pre-service teachers to engage with their own religious identity paradigms. This has the potential to be empowering and transformative in religiously diverse classroom contexts and indeed, for the wider society.

Keywords: personal history self-study, religious identity paralysis, religious identity paradox, religious identity flexibility, religious identity transformation, self-dialogue, self-narrative 


\section{Introduction}

My purpose in this personal history self-study (Samaras, Hicks \& Garvey Berger 2007) is to visit and reflect upon my engagement with Religion Education during various periods in my life, with the intention of improving my current practice as a teacher educator. As I endeavour to trace the formative, contextualised experiences that have influenced my practice, I hope to produce insights that could be of use to the pre-service teachers with whom I engage, many of whom struggle at the intersection of their own religious identities and the religious diversity they encounter in the classroom and in the wider society.

Currently, many of my pre-service teachers, notwithstanding a curriculum that promotes religious diversity, nevertheless continue to prepare lessons with a mono-religious focus. An example is the recent task that I set both undergraduate and post-graduate pre-service teachers. They were required to design a series of Religion Education lessons for Grade 5 learners focusing on religious festivals. Several of their lessons focused on Christian festivals only and this, from a particular Christian perspective. The stated values/ attitudes underpinning these lessons included respect for religious diversity and yet, the lessons presented as mono-religious.

In telling and interpreting my personal history, I hope to unpack the tensions that I experienced and to reflect upon how I made the shift from a mono-religious approach to teaching Religion Education, moving to a multireligious approach, and then adopting more recently, an empathetic-reflectivedialogical approach (Jarvis 2018). Furthermore, I hope to inform my practice with the aim of helping my pre-service teachers to do the same.

I hope to address the following questions:

- How and why has my approach to teaching Religion Education changed over time?

- How can I assist pre-service teachers to adopt an inclusive approach to religious diversity?

In tracing my trajectory, I articulate my personal history against the historical backdrop of the national curriculum policy in South Africa. My 
personal history self-study focuses on the following three periods of my life: as a secondary school teacher (1983-1993); as a senior teacher educator at a former college of education (1994 - 1999); and as a teacher educator at a South African university (2000 - the present).

\section{Methodology}

During the 1980s scholars began to use biographical forms of inquiry, including personal histories and experiences, so as to gain a better understanding of their practice (Gough 2015; Bullough \& Pinnegar 2001). While such methodologies were initially questioned as lacking in academic substance, there has been considerable growth in the degree to which they are now accepted as making academically worthwhile contributions to the generation of knowledge (Mitchell 2004; Samaras, Hicks \& Garvey Berger 2007; Hayler $\&$ Moriarty 2017). These methodologies aim to use personal experience as a resource and to problematize this in an endeavour to reframe and better understand individual beliefs, understandings and practices so as to improve upon them (La Boskey 2004; Hayler \& Moriarty 2017). According to Samaras, Hicks and Garvey Berger (2007:905) personal history self-study is increasingly becoming an essential methodology towards teacher educator's personal and professional growth and especially to improving their teaching practice and impacting their students' learning. Personal history self-study is improvement-oriented and it seeks reframed thinking and transformed practice, involving as it does, intentional and systematic inquiry into one's own practice (Dinkelman 2003:8). Using this particular methodology, I become both participant and researcher stepping in and out of the story (Reed-Danahay 1997: 6). Demonstrating both refection and reflexivity I ask how and why I have engaged in teaching-learning (Jacobs, Vakalisa \& Gawe 2011) in the way that I have. Hayler and Moriarty (2017) posit that this is a key element of being a teacher. The analytic process takes place within the planning and construction of my personal narrative (Richardson 2000).

In this article, I reflect upon the attitudes, beliefs and actions that have had a bearing on my teaching of Religion Education. I trace my personal experience of teaching Religion Education and identify the positions that I have adopted along the way. I pay particular attention to how my position has changed over time. Personal and political struggles are an integral part of the journey and these are discussed against a backdrop of national policy. As the 
source of data representation in this study, I draw on what Clandinin and Connelly (1994) refer to as the power of my personal history to awaken and educate others and myself.

In contextualising my personal history self-study, I will present the narrative of my religious identity using to the following sub-headings:

- Religious Identity paralysis: a mono-religious approach to teaching Religion Education

- Religious Identity paradox: a mono-religious approach to teaching Religion Education

- Religious identity flexibility: a multi-religious approach to teaching Religion Education

- Religious identity transformation: an empathetic-reflective-dialogical approach to teaching Religion Education

I then interpret the narrative of my personal history through the lens of Hermans' (2011) dialogical self theory and that of religious identity capital, drawing on the work of Côté (2005).

\section{Personal History Self-study}

My personal history has to be considered against the socio-political, historical, cultural and familial context in which I was raised. In this way the autobiographical begins to merge with the autoethnographical (Reed-Danahay 1997). My childhood home was not particularly religious, although my parents did follow aspects of the Christian faith in a very nominal way. I became a committed, practising Christian in 1974 when I was 13 years old. My personal exposure to Christianity has been especially broad and has included exposure to both Catholicism and Protestantism. I attended a Catholic convent school from Grades 1 - 12. During my school years, I attended the neighbourhood Anglican Church until my parents decided that the church was too political and insisted that I leave. Thereafter, on Friday nights I attended a youth group run by the local Methodist Church while, on Sundays, I accompanied my mother when she started attending the local Presbyterian Church. In 1978, when I started my tertiary studies at a university in Pietermaritzburg, I attended the 
local Presbyterian Church but also visited Pentecostal churches in the area. During this time, I was also involved in both the Anglican Students' Association and the non-denominational Students' Christian Association on campus.

In respect of my religious identity, while I began to engage in intra-religious dialogue, moving as I did from one Christian denomination to another, I experienced something of a paralysis in respect of inter-religious dialogue. The mono-religious environments that I experienced and the mono-religious approach, to which I was exposed at school, caused me to want to engage with my Christianity only and to be unwilling to enter spaces that were religiously diverse. Since Christianity is exclusive in nature, I was exhorted to disregard any religion other than my own and I readily accepted this position. Significantly, it meant that I was ill equipped and unprepared as a student at university to engage with any religious worldview other than my own. I felt uncomfortable in the multi-religious environment in which I found myself, and this discomfort entrenched a religious identity paralysis. I dealt with this by immersing myself in the activities of the Christian student societies mentioned previously. I seldom engaged with students who believed differently.

In South Africa at the time, the ruling nationalist party professed a Christian faith and purported to govern according to strongly Calvinist 'Christian' principles. Writing in 1999 (p. 3), Prozesky and De Gruchy indicated that,

politics and history have so far ensured that there has been, and still is, no real equality of faiths in this country. Certain kinds of Christians, particularly among whites have greatly dominated the religious and political stage. A religion with daily or weekly access to public funded television or to the nation's classrooms can make its voice heard and its presence felt much more effectively than religions to which these things have been denied.

This Calvinist Christianity found expression in classrooms as Christian National Education (CNE) and it was this ideological framework that taught children that apartheid could be justified on Christian grounds.

\section{Religious Identity Paralysis: A Mono-religious Approach to Teaching Religion Education}


My teaching trajectory commenced in the early 1980s during which time CNE continued to be the official education policy of the National Party. The dubious amalgam of religion and nation was expected to extend to all classroom teaching and to support Youth Preparedness and Veld School programmes (Rose \& Tunmer 1975). Religion Education, which was known by various names, including Religious Instruction, Bible Education or simply Scripture, was a compulsory school subject and its teaching required a specific technicist approach. The rigid form of Calvinism that constituted the Christian element in CNE (Jarvis \& Moodie 2009) directly influenced teaching methodologies. Learners were presented with Biblical truths, as they were understood within the same. They were required to accept these with little or no questioning and because of the association with the State, their obedience and conformity drew strong parallels with loyalty to the ruling party. Having been raised in a white middle class home by politically conservative parents, and not having developed a critical religious stance at university, this component of CNE was not entirely unfamiliar to me and, certainly for a while initially, I was not entirely uncomfortable with it, bounded as I was by my own religious identity. Increasingly, however, a point of tension did emerge as I became more aware of the diversity of religious beliefs represented in my classroom, to a lesser extent, but definitely in the wider society. A mono-religious approach certainly did not accommodate this diversity.

\section{Religious Identity Paradox: A Mono-religious Approach to Teaching Religion Education}

In 1988, having taught for five years in former white-only schools in what was then the province of Natal, my discomfort at ignoring religions other than Christianity, as well as Christian denominations which were different from the Calvinism promoted by the state, continued to grow. I began to experience something of a religious identity paradox and a measure of uneasiness at the marginalisation of religions other than my own. I still struggled, however, to adopt a progressive, multi-religious approach in the classroom as I felt that this would be tantamount to a betrayal of my religious position and the CNE approach, and so the paradigm shift was a difficult and slow one to make.

As I now reflect on those years I draw on Giddens (2002) and Bendle (2002) who speak of multiple identities in respect of substantial (personal) and situational (professional) identities. In my case, my personal religious identity 
and the professional identity required of me by $\mathrm{CNE}$ were in many ways synonymous. However, my growing discomfort in marginalising religions other than the state religion increased and, as I started to question the required mono-religious approach to teaching Religious Education, I experienced what Jansen (2001) describes as an identity conflict.

During my allotted Religious Education periods, I encouraged my learners to develop religious literacies that were reflective of the diversity of religions represented in South Africa. I adopted a comparative approach in which I would look at certain topics and do so from the perspective of the major religions represented in the country, and in particular, Christianity, Judaism, Hinduism and Islam. Topics for inclusion would typically include places of worship, holy writings, signs/symbols, religious heroes, festivals, diet and rituals. I did not include Traditional African Religion and the African Independent Churches, since at the time I did not consider them to have significance. This was a reflection of my limited worldview at the time. As such I engaged in teaching superficially about the different religions. At no point did I create the space to reflect empathetically, or engage dialogically with each religion. While I now know that my approach was very inadequate, I think that I nevertheless did afford my learners some opportunity to begin to think about religious diversity and to develop some form of religious literacy. School management members frowned upon my approach and strongly advised me to pursue the mono-religious approach required by $\mathrm{CNE}$.

In 1992, I was promoted to the position of Head of Department at a different school in the greater Durban area. At the same time, I was asked to serve on a provincial Religious Education subject committee. It was in this forum, that I was exposed to information and debate that clearly indicated that the political climate in the country was beginning to change. I felt compelled to reflect critically upon my own trajectory in order to engage with the way forward in embracing religious diversity. I questioned my religious identity and the influence that I exercised in the classroom. I reflected on my possible contribution to educational transformation. I began to research possible teaching-learning approaches that I could employ to promote inclusivity in a religiously diverse classroom. My perceptions and attitudes towards Religious Education were changing and developing.

During this period of embryonic change in my professional practice, discussions had already commenced at a national level leading up to the release of Nelson Mandela and the 1994 elections. It was in the same year that I was 
appointed as a senior teacher educator to a Biblical Studies position at a former college of education.

\section{Religious Identity Flexibility: A Multi-religious Approach to Teaching Religion Education}

The foundational principles of the new Constitution of the Republic of South Africa (Republic of South Africa 1996) are enshrined in the cross-curricular outcomes to which all South African education, in all forms and at all levels are directed. In state schools, Christianity, not least CNE, was rejected as the sole bearer of the beliefs and values, realities and challenges, of the diverse peoples of South Africa (Roux 2012b). Following the democratic elections in 1994 pre-service teachers have been prepared for an inclusive approach to the provision of schooling. The introduction of Curriculum 2005 signalled a decisive new beginning, when under the leadership of Education Minister Kader Asmal, Outcomes Based Education (OBE) was introduced. OBE sought to eradicate the indoctrination of the CNE period by focusing on integrated and learner-centred learning guided by generic and specific outcomes, and positioned to take account of the religious diversity of the country.

The aims of the Constitution of the Republic of South Africa (Republic of South Africa 1996) are presented in the introduction to the National Curriculum Statement (Department of Education 2003a), and again in the Statements for each of the learning areas of the curriculum, including Life Orientation (LO) (Department of Education 2003b). LO was introduced with the intention of developing the self-in-society. As such, this learning area focused on the personal, social and physical development of learners. Religious Education, formerly a stand-alone subject, was included as an aspect of the learner's social development within LO, and was renamed Religion Education. In 2003, the National Policy on Religion and Education (Department of Education 2003c) was introduced providing a framework for teaching within a context of religious diversity. This document promotes the importance of religion in society and outlines professional approaches for teaching and learning as well as teacher training. The National Policy on Religion Education (Department of Education 2003c) clearly explains the difference between Religious Instruction (a hallmark of CNE) and Religion Education, and encapsulated in the phrases unity but not uniformity and diversity not divisiveness (Department of Education 2003c: 24), is the co-operative, inclusive approach which is adopted. 
Against this backdrop, as a teacher educator at a former college of education, I assisted pre-service teachers to function as citizens and teachers in a diverse society and to this end, I developed modules aimed at enabling them to engage with a multi-religious approach to Religion Education. I aimed to facilitate the intellectual development of these pre-service teachers in respect of preparing them to engage meaningfully with the new realities of society and to teach their learners accordingly.

I observed that many of the pre-service teachers struggled with this, for in many ways I was requiring them to unlearn what they had learned over many years at school and in their home environments. Paradigms and mindsets had to be deconstructed and critically engaged with, yet the Department of Education assumed that both pre-service and in-service teachers would be able to make this transition with ease and within a relatively short period of time.

During this period of change former colleges of education were, in 2002, incorporated, into Institutions of Higher Education and college staff were required to apply for jobs at the universities. I was successful in my application and found myself in the position of teacher educator in a newly formed Faculty of Education in a local university. These institutional changes were accompanied by an influx of pre-service teachers of diverse religious backgrounds, people with whom I had had limited contact.

In 2005, I was invited to be a researcher in an international project funded by the Netherlands, which focused on understanding human rights through different belief systems (Roux, Smith, Ferguson, Small, Du Preez \& Jarvis 2006). Aware of the difficulties in-service teachers were experiencing facilitating Religion Education in multi-religious contexts, and as part of the broader project, I embarked on a Master's research project (Jarvis 2008) in which I interviewed LO teachers in selected primary schools. These schools were populated with learners from a diversity of religions. The findings showed that the assumption made by the Department of Education was misguided in that while the in-service teachers had an understanding of religious freedom as a human right, they experienced great difficulty maintaining their own religious identity while teaching about religions other than their own. 
Tensions between personal religious identity and professional identity became apparent. Participants like Bona ${ }^{1}$ and Emily maintained a monoreligious approach saying:

I think that Christianity is the right way and only that should be practised. Once you involve in practising other religion, automatically it affects your own religious beliefs. (Bona)

You are determined in what you believe and don't alter on those beliefs... so right now we have got to promote that. (Emily)

Other participants highlighted the lack of inclusion of religious diversity.

I do believe the learners at this school have to compromise their beliefs. There is no religious freedom ... we don't ever really pay specific attention to any other religions other than Christianity... We are not allowed to discuss things openly at meetings. (Purity)

... there are people who are African Christians but their religious freedom is not taken into consideration. (Siya)

One religion is promoted just because more learners are from that religion so others are neglected because they are few members from different religions. (Jabu)

...we are certainly not being fair to non-Christian learners. The other religions are not fully considered. (Angela)

My Master's research provided a critical moment in my personal history, providing the opportunity for me to adopt an inquiring stance pertaining to identity dissonance (Costello 2004) between my substantial self and situational self. I engaged in research and was able to participate in the development of academic discourses which explored this distinctive field of study and research in Religion Education.

${ }^{1}$ Pseudonyms are used in the interest of anonymity. 
In reflecting upon this period, I now realise that the religious identity dissonance that I was experiencing hindered my moving forward in my approach to teaching Religion Education. While I was effectively encouraging changed attitudes and promoting an interest, awareness and openness to religions, I doubted my impact in challenging mono-religious mind-sets and promoting a multi-religious approach with the specific intention of facilitating transformation in society. Simply knowing about different religions and adopting an inclusive, multi-religious approach to Religion Education does not engage with issues including prejudice, suspicion and stereotyping.

As I immersed myself in academia, attended conferences and read widely in the field of Religion Education, I found that my perceptions began to change and I was able to respond to diversity and difference with growing critical awareness, appreciation and enthusiasm. I was experiencing what I refer to as religious identity flexibility (Jarvis 2009a). Being secure in my own religious identity, I found that I was able to consider empathetically, the practice and traditions of religions other than my own, without feeling compromised or threatened. In doing so, I was able to express a measure of individual agency. While I adopted a multi-religious approach to Religion Education, I was nevertheless able to remain committed to my personal religious identity. As my confidence grew, I found that I was able to teach in a way to enable my pre-service teachers to engage in the same manner. As a follow on from this, I was able to place my teaching and their learning within the broader context of human rights so painstakingly enshrined in the Constitution of the Republic of South Africa (Republic of South Africa 1996) and the Manifesto on Values, Education and Democracy (Department of Education 2001). I did so fully recognising the significance and need for understanding and engaging with Religion Education.

In 2011, in recognition that OBE had been a failure in the South African context (the reasons for this extending beyond the scope of this article), the current Curriculum and Assessment Policy Statement (CAPS) (Department of Education 2011a) replaced Curriculum 2005. Religion Education was situated in the subject Life Skills (Grades R -6)/ Life Orientation (Grades 7 12) (Department of Education, 2011b; 2011c; 2011d). The National Policy on Religion and Education (Department of Education 2003c) continued to guide the approach to religious diversity in schools and more specifically in the curriculum. 


\section{Religious Identity Transformation: An Empathetic-reflective- dialogical Approach to Teaching Religion Education}

With time, my on-going reading and research led me to realise that human rights education based on critical engagement, required more than my earlier rather simplistic approach, merely teaching about religions, albeit that I increased pre-service teacher's religion literacy. After completing my $\mathrm{PhD}$ research (Jarvis 2013a; 2013b), I sought a more creative approach to overcome sedimented or inherited ways of being (Jackson \& Mazzei 2017: 720). This led me to explore an empathetic-reflective-dialogical approach (Jarvis 2018) to teaching Religion Education. This empathetic approach included the capacity to understand and respond to the religious experiences of another person with an increased awareness of that person's thoughts and feelings, and an awareness that for them their religion is holy ground. Reflection is defined by McCormack and Kennelly (2011: 517) as the examination of responses, beliefs and premises resulting in the integration of new understandings into experience. The dialogical aspect of this approach concerned the search for meaning and understanding (Allen 2004), recognising that each person has ... something of value to contribute; it is about opening [up] to the possibility of learning from the other (Ipgrave 2001: 7). Dialogical activity recognises the individuality of religious thinking and provides an opportunity to explore this (Jarvis 2009b). I experienced a religious identity transformation as I employed this empathetic-reflective-dialogical approach (Jarvis 2018). It is this approach to Religion Education that I currently teach and model in both my undergraduate and post-graduate classes.

\section{Interpreting the Narrative of my Personal History}

- How and why has my approach to teaching in Religion Education changed over time?

My personal narrative highlights the tensions that I experienced between my situational and substantial identities. It demonstrates that I have made the shift from religious identity paralysis to religious identity transformation and from a mono-religious approach to an empathetic-reflective-dialogical approach to teaching Religion Education. I use the lens of the Dialogical Self Theory 
(Hermans 2011; Hermans \& Hermans-Konopka 2010) and that of religious identity capital (Côté 2005) to interpret my personal narrative and to show how this shift took place. This, with a view to informing my practice and creating opportunities for my pre-service teachers to do the same.

In order to employ this empathetic-reflective-dialogical approach to teaching Religion Education I first had to be comfortable with my own religious identity and religious discourse. I had to be sufficiently secure therein to be able to empathically investigate the practice and traditions of other religions represented in my classroom and in the broader South African society. While not having to compromise my religious identity, I knew that I would need to be able to take account of the rights of others which had the status of being nothing but different from my own. Notions of superiority and inferiority could not be accommodated (Baez 2000).

As my thinking continued to unfold I found that more and more I needed to reflect on and explore my religious identity (Samuel \& Stephens 2000). I had to place my substantial self, namely, my own Christian beliefs and my position as a leader in a non-denominational Christian church, in parenthesis (Jackson 1997), and adopt an impartial yet empathetic approach to the beliefs of others.

I place much store by my Christian faith. It has sustained me through difficult times in my life and has given me a sense of worth, dignity, courage and purpose. In many ways, engaging in this personal history self-study has had the effect of strengthening my own particular faith position. Engaging with other faith positions has encouraged me increasingly to understand my own religious discourse.

The metaphor of the polyphonic novel (Bhaktin 1981) opened the possibility of the internal space of my mind being populated with a multiplicity of voices that, at the beginning of my transition at least, were quite substantially at variance with each other. While I live in an external space, namely my society and culture, I also live in the internal space of my mind. The many individuals that make up society resonate with certain of the voices in my mind. Hermans (2011) refers to this as the society-of-mind.

Collective voices in the dialogical self (Hermans \& Hermans-Konopka 2010) belonging to external groups and institutions, including religions and cultures, can organise and constrain the individual's worldviews and convictions. The dominant collective voices of my mono-religious discourse paralysed my religious identity and I was unable to consider making a shift. As 
I became more aware of religious diversity and allowed other voices to permeate my society-of-mind I found myself in a state of discomfort that resulted in religious identity paradox, however, I remained unsure as to how to make a shift to inclusivity.

Bhaktin's (1981) notion of surplus vision helped me to understand that as I engaged increasingly with religious diversity, in the internal space of my mind, I needed to see the other from the place of the other. The other here refers to those adhering to religions other than my own. This afforded me the space in my society of mind to entertain voices representing religious diversity and I was able to adopt a multi-religious approach to teaching Religion Education. An empathetic approach allowed me to do this as I acknowledged that religions other than mine are holy ground for their adherents.

Adopting a meta-position (Hermans \& Hermans-Konopka 2010) provided me with a broad perspective of religious identity. When I reflected on positions both within and between my internal and external domains, dialogical relationships emerged with the possibility of developing and creating new attitudes and approaches (Hermans \& Dimaggio 2007) both as an individual and as a teacher educator. Understanding my dialogical self has the potential of being transformative.

My dialogical self was always tied to a particular position in space and time, but as I adopted a counter-position (Hermans \& Hermans-Konopka 2010, p.108) to dominant voices promoting a mono-religious approach I exercised agency (Gallagher 2012) and was able to choose to engage meaningfully with religious diversity.

My dialogical self in action (Hermans \& Dimaggio 2007) resulted in the movement from religious identity paralysis to religious identity paradox to religious identity flexibility to religious identity transformation as I gained understanding about myself in relation to the world (Hermans \& HermansKonopka 2010). I developed the capacity to deal with tensions, contradictions and uncertainties (Cooper \& Hermans 2006) in religiously diverse teaching contexts. This also empowered me to reconcile my substantial self and situational self.

Every time I adopted a counter-position to a mono-religious or superficial multi-religious approach to religions that are other to my own, without compromising my own faith, I built the strength and extent of my religious identity capital. This refers to the stock of resources, or set of strengths (Côté \& Levine 2002: 164) I have when constructing, framing and presenting my 
transformed religious identity in particular social circumstances. My religious identity capital consists of tangible resources such as my commitment and membership of a particular religious group, and intangible resources which include my ability to engage and reflect, and negotiate my religious identity (Côté 2005; Côté \& Levine 2002). The accumulation of successful identity exchanges, namely my social interaction and professional engagement with those belonging to religions different to my own, without compromising my personal religious identity, increases my religious identity capital (Côté \& Levine 2002). It is from this religious identity capital that I draw as I employ an empathetic-reflective-dialogical approach to teaching Religion Education.

In the narrative of my personal history I identified the tensions that challenged me to explore my approach to teaching Religion Education (the why). The lens of the dialogical self theory and religious identity capital were useful to interpret this self-narrative and to explain how I was able to change my approach to teaching Religion Education. I now move to a consideration of how I can help my pre-service teachers to embark on this on-going journey with me.

- How can I assist pre-service teachers to adopt an inclusive approach to religious diversity?

When interpreting my personal history self-study I discovered that taking an inquiring stance and becoming a researcher made the difference in my understanding of my journey. I need to create the opportunity for my preservice teachers to do the same. One of the ways in which I can facilitate this process is by encouraging my pre-service teachers to adopt an inquiring stance as they engage critically with key issues in society and consider these from the perspective of a diversity of religious discourses.

I engaged in initial self-reflection and a process of religious identity negotiation (Nias 1985; 1989) between my substantial self and situational self, and I need to create spaces for my pre-service teachers to do the same. They need to be able to explore their own religious identities whilst at the same time developing a religious literacy and religious empathy that would enable them to engage within a context of religious diversity. I need to model for them, as I have explained above, how to put into parenthesis their own religious identity while not necessarily undermining the same (Jackson 1997; Jarvis 2008). 
In assisting them to build their religious identity capital, I need to create space for them to explore their self-dialogue and to consider counter positions to dominant discourses by employing their dialogical self in action, building the extent and strength of their religious identity capital as they do so. This can be done as I initiate intra- and inter-religious dialogue with my preservice teachers where they can empathetically engage with one another, reflecting on their self-dialogue and expressing this in their self-narratives in a Community in Conversation (CiC) (De Wet \& Parker 2014; Roux 2012a). As a teaching methodology a $\mathrm{CiC}$ has the potential to provide the opportunity for the exchange of perspectives and personal experiences in a safe space (Du Preez 2012; Roux 2012a), denoting the figurative and discursive use of the notion (Du Preez 2012; Redmond 2010; Stengel \& Weems 2010). The aim of the $\mathrm{CiC}$ would be to understand self-respect and own positionality, foster respect for each other, and inspire reciprocal exchanges with empathetic understanding.

Providing pre-service teachers with the opportunity in a $\mathrm{CiC}$ for individual voices to be heard in the midst of dominant discourses, and for perspectives and personal experiences to be exchanged, has the potential to foster respect, trust and tolerant understanding as ...divergent ways of thinking and speaking (McCormack \& Kennelly 2011: 522) are reflected upon. Empatheticreflective-dialogue within a $\mathrm{CiC}$ has the potential to lead to the emergence of collaborative initiatives for the transformation of classroom practice to classroom praxis (McCormack \& Kennelly 2011; Roux \& Du Preez 2006).

Employing an empathetic-reflective-dialogical approach as a teacher educator will model something for the pre-service teachers as together, we critically engage with perspectives of different religions in an environment that encourages both intra- and inter-religious dialogue. In the process, we have the opportunity to use our own dialogical voices (Jarvis 2009b). However, adopting a Foucaultian perspective, I would emphasise that this methodology is never prescriptive, at most it is instrumental and tentative. This type of research troubles both knowledge and reality and how such knowledge and reality are produced (Jackson \& Mazzei 2012: 720). As we search for meaning and understanding, we get to know more about our own perspectives as well as perspectives that are different from our own. Such dialogue has the potential to be emancipatory and transformational (Allen 2004). 


\section{Conclusion}

The reflection on, and analysis of my personal history and lived experience within the particular socio-political, historical, cultural and familial contexts which I have described, informs and contributes to the ethos, method and content of my teaching. Who I am affects my role as a teacher educator and consequently what my pre-service teachers will learn (Samaras et al. 2007). Engaging with my personal history self-study has helped me to understand how, and why, my approach to teaching Religion Education has changed over time. My past and present are linked in a spiral of interpretation and reinterpretation. My self-dialogue, in my society-of-mind, has played a pivotal role in my religious identity construction in responding to the situated knowledges (Haraway 1991) of my life. On the one hand, the dialogical self theory acknowledges that my position in society has been determined by my birth and my personal religious discourse. On the other hand, as I have engaged my dialogical self in action, and as the extent and strength of my religious identity capital has increased, I have exercised agency by promoting an empathetic-reflective-dialogical approach to teaching Religion Education. While I, in this article, have reflected upon my own experience, the methodology I have pursued is open to use by other teacher educators (not least in Religion Education) as they in in turn, reflect upon how and why they engage in teaching-learning in the way they do.

My personal history self-study has facilitated transformative learning both for myself as teacher educator, and for my pre-service teachers. By applying what I have learnt to my professional practise, the possibility exists that I will be able to equip my pre-service teachers to engage in both reflective and reflexive practice together with their learners. Furthermore, I would argue that by adopting an empathetic-reflective-dialogical approach, these teachers would be well positioned to contribute meaningfully to the establishment of schools as thinking communities (Green 2014) in which their classroom practice becomes classroom praxis. In such schools learners have the potential to become change agents in the diverse religious landscape in South Africa as they in turn practice an empathetic-reflective-dialogical approach to religious discourses other than their own. This could be transformative for the wider South African community.

\section{References}


Allen, L. 2004. From Votes to Dialogues: Clarifying the Role of Teachers' Voices in School Renewal. Phi Delta Kappan 218 - 321. Available at: https://doi.org/10.1177/003172170408600416

Baez, B. 2000. Agency, Structure, and Power: An Inquiry into Racism and Resistance for Education. Studies in Philosophy and Education 19,4: 329

- 348. Available at: https://doi.org/10.1023/A:1005241732091

Bakhtin, M. 1981. The Dialogic Imagination. Austin, Texas: University of Texas Press.

Bendle, M.F. 2002. The 'Crisis' of Identity in High Modernity. The British Journal of Sociology 53, 1: 1 - 18. Available at:

https://doi.org/10.1080/00071310120109302

Bullough, R.V. \& S. Pinnegar 2001, Guidelines for Quality in Autobiographical Forms of Self-study Research. Educational Researcher 30, 3: 13 21. Available at:

https://doi.org/10.3102/0013189X030003013

Clandinin, D. \& F. Connelly 1994. Personal Experience Methods. In Denzin, N. \& F. Y. Lincoln (eds.): Handbook of Qualitative Research. Thousand Oaks, CA: Sage.

Cooper, M. \& H.J.M. Hermans 2006. Honoring Self-otherness: Alterity and the Intrapersonal. In Simao, L. \& J. Valsiner (eds.): Otherness in Question: Labyrinths of the Self. Greenwich, CT: Information Age.

Costello, C.Y. 2004. Changing Clothes: Gender Inequality and Professional

Socialization. NWSA Journal 16, 2: 138 - 155. Available at:

https://doi.org/10.2979/NWS.2004.16.2.138

Côté, J. 2005. Identity Capital, Social Capital and the Wider Benefits of Learning: Generating Resources Facilitative of Social Cohesion. Journal of Adolescence 20: 577 - 597. Available at:

https://doi.org/10.1006/jado.1997.0111

Côté, J, \& C. Levine 2002. Identity Formation, Agency and Culture: A Social Psychological Synthesis. Mahwah, NJ: Lawrence Erlbaum Associates Publishing.

Department of Education 2001. Manifesto on Values, Education and Democracy. Pretoria: Government Printers.

Department of Education 2003a. Revised National Curriculum Statement. Pretoria: Government Printing Works.

Department of Education 2003b. Revised National Curriculum Statement: Life Orientation. Pretoria: Government Printing Works. 
Department of Education 2003c. National Policy on Religion and Education.

Pretoria: Government Printing Works.

Department of Basic Education 2011a. Curriculum and Assessment Policy (CAPS). Pretoria: Government Printing Works.

Department of Basic Education. 2011b. Curriculum and Assessment Policy (CAPS): Life Orientation FET (10-12). Pretoria: Government Printing Works.

Department of Basic Education 2011c. Curriculum and Assessment Policy

(CAPS): Life Orientation Grades 7-9. Pretoria: Government Printing Works.

Department of Basic Education 2011d. Curriculum and Assessment Policy (CAPS): Life Skills Grades 4-6. Pretoria: Government Printing Works.

De Wet, A. \& G. Parker 2014. Communities in Conversation: Opportunities for Women and Girls' Self-empowerment. Gender and Development 22,

1: 109 - 125. Available at:

https://doi.org/10.1080/13552074.2014.889341

Dinkelman, T. 2003. Self-study in Teacher Education: A Means and Ends Tool for Promoting Reflective Teaching. Journal of Teaching Education 54, 1: 6 - 19. Available at:

https://doi.org/10.1177/0022487102238654

Du Preez, P. 2012. A Human Rights Based Curriculum for Religious Schools:

The Responsibilities of School Leaders. In Buchanan, M. (ed.): Effective

Leadership for Religious Schools: What Leaders Should Know. USA:

Continuum Publishing.

Gallagher, S. 2012. Epilogue: A Philosophical Epilogue on the Question of Autonomy. In Hermans, H. \& T. Gieser (eds.): Handbook of Dialogical Self Theory. Cambridge, UK: Cambridge University Press.

Giddens, A. 2002. Modernity and Self-Identity: Self and Society in the Late Modern Age. Great Britain: TJ International Ltd.

Green, L. 2014. Schools as Thinking Communities. Pretoria: Van Schaik.

Gough, N. 2015. Rewording the World: Narrative and Nature after Poststructuralism. In Robertson, M., R. Lawrence \& G. Heath (eds.): Experiencing the Outdoors: Enhancing Strategies for Wellbeing. Amsterdam: Sense Publishers.

https://doi.org/10.1007/978-94-6209-944-9_19

Haraway, D.J. 1991. Simians, Cyborgs, and Women. London: Free Association Books. 
Hayler, M. \& J. Moriarty 2017. Self-Narrative and Pedagogy: Stories of Experience within Teaching and Learning. Rotterdam: Sense Publishers. Available at:

https://doi.org/10.1007/978-94-6351-023-3

Hermans, H.J.M. 2011. The Dialogical Self: A Process of Positioning in Space and Time. In Gallagher, S. (ed.): The Oxford Handbook of the Self. Oxford, UK: Oxford University Press.

https://doi.org/10.1093/oxfordhb/9780199548019.003.0029

Hermans, H.J.M. \& G. Dimaggio 2007. Self, Identity, and Globalization in Times of Uncertainty: A Dialogical Analysis. The American Psychological Association 11, 1: 31 - 61. Available at:

https://doi.org/10.1037/1089-2680.11.1.31

Hermans, H.J.M. \& A. Hermans-Konopka 2010. Dialogical Self Theory: Positioning and Counter-positioning in a Globalizing Society. Cambridge, UK: Cambridge University Press. Available at:

https://doi.org/10.1017/CBO9780511712142

Ipgrave, J. 2001. Pupil-to-Pupil Dialogue in the Classroom as a Tool for Religious Education. Paper presented at the Warwick Religions and Education Research Unit.

Jackson, R. 1997. Religious Education: An Interpretive Approach. Great Britain: Hodder \& Stoughton Educational.

Jackson, A.Y. \& L. Mazzei 2012. Thinking with Theory: A New Analytic for Qualitative Inquiry. In Jackson, A.Y. \& L. Mazzei (eds.): Thinking with Theory in Qualitative Research. New York: Routledge.

Jacobs, M., N. Vakalisa \& N. Gawe 2011. Teaching - Learning Dynamics. South Africa: Pearson Education.

Jansen, J. 2001. Image-ining Teachers: Policy Images and Teacher Identity in South African Classrooms. South African Journal of Education 21, 4: 242 $-246$.

Jarvis, J. 2008. The Voice of the Teacher in the Context of Religious Freedom: A Kwazulu-Natal Case Study. Unpublished Master of Education full dissertation, Stellenbosch University, Stellenbosch.

Jarvis, J. 2009b. The Voice of the Religion Education Teacher in a Context of Religious Diversity. Alternation Special Edition 3: 138 - 156. Available at:

http://alternation.ukzn.ac.za/Files/docs/Alternation\%20Spec\%20Ed\%20 3\%20Pdfs/07\%20Jarvis\%20FIN[1].pdf 
Jarvis, J. 2009a. Teacher Identity in a Context of Religious Diversity. Alternation Special Edition 3: 157 - 176. Available at:

http://alternation.ukzn.ac.za/Files/docs/Alternation\%20Spec\%20Ed\%20 3\%20Pdfs/08\%20Jarvis\%20FIN[1].pdf

Jarvis, J. 2013a. Female Teachers' Religious and Cultural Identities and Gender Equality. PhD thesis. Potchefstroom: North West University. Jarvis, J. 2013b. Paving the Way to Transformation: Student Teachers' Religious Identity and Religion Education. Alternation Special Edition 10: 131 - 147. Available at:

http://alternation.ukzn.ac.za/Files/docs/20.7/07\%20Jar.pdf

Jarvis, J. 2018. Restorying for Transdisciplinarity: A Proposed Teachinglearning Strategy in a Context of Human Rights Education. The Journal for Transdisciplinary Research in Southern Africa 14: a483. Available at: https://doi.org/10.4102/td.v14i2.483

Jarvis, J. \& C.A.E. Moodie 2009. Recent Developments in Theology and Religious Studies - The South African Experience. In Bird, D. \& S. Smith (eds.): Theology and Religious Studies in Higher Education: Global Perspectives. London: Continuum International Publishing Group.

LaBoskey, V.L. 2004. The Methodology of Self-study and its Theoretical Underpinnings. In Loughran,J.J., M.L. Hamilton, V.K. LaBoskey \& V.K. Russell (eds.): International Handbook of Self-study of Teaching and Higher Education Practices. Kluwer: Dordrecht. Available at: https://doi.org/10.1007/978-1-4020-6545-3_21

McCormack, C. \& R. Kennelly 2011. 'We must get together and really talk ...' . Connection, Engagement and Safety Sustain Learning and Teaching Conversation Communities. Reflective Practice 12, 4: 515 - 531. Available at:

https://doi.org/10.1080/14623943.2011.590342

Mitchell, C. 2004. Just Who do We Think We are? Self-study through Memory and Reflection in a Pre-service Education Programme. In Balfour, R., T. Buthelezi \& C. Mitchell (eds.): Teacher Development in the Centre of Change. Durban: KwaZulu-Natal Department of Education, Teacher Development Directorate, Faculty of Eduation, Universty of KZN.

Nias, J. 1985. Reference Groups in Primary Teaching: Talking, Listening and Identity. In Ball, S. \& I. Goodson (eds.): Teacher's Lives and Careers. London: Falmer Press. 
Nias, J. 1989. Primary Teachers Talking: A Study of Teaching as Work. London: Falmer Press.

Prozesky, M. \& J. de Gruchy (eds.) 1995. Living Faiths in South Africa. London: Hurst and Company.

Redmond, M. 2010. Safe Space Oddity: Revisiting Critical Pedagogy. Journal of Teaching in Social Work 30: 1 - 14. Available at:

https://doi.org/10.1080/08841230903249729

Reed-Danahay, D. 1997. Auto/ethnography: Rewriting the Self and the Social. Bloomsbury Academic.

Republic of South Africa 1996. The South African Constitution. Pretoria: State Printers.

Richardson, L. 2000. 'Writing: A Method of Inquiry. In Denzin, N. \& Y. Lincoln (eds.): Handbook of Qualitative Research. Thousand Oaks, CA: Sage.

Rose, B. \& R. Tunmer 1975. African Education. In Rose, B. \& R. Tunmer (eds.): Documents in South African Education. Johannesburg: AD Donker.

Roux, C.D. 2012a. A Social Justice and Human Rights Education Project: A Search for Caring and Safe Spaces. In Roux, C. (ed.): Safe Spaces: Human Rights Education in Diverse Contexts. Rotterdam: Sense Publishers. https://doi.org/10.1007/978-94-6091-936-7

https://doi.org/10.1007/978-94-6091-936-7_3

Roux, C.D. 2012b. Conflict or Cohesion? A Critical Discourse on Religion in Education (RiE) and Religion and Education (RaE). In Ter Avest, I. (ed.): On the Edge: (Auto)biography and Pedagogical Theories on Religious Education. Rotterdam: Sense Publishers.

Roux, C.D. \& P. du Preez 2006. Clarifying Students' Perceptions of Different Belief Systems and Values: Prerequisite for Effective Education Praxis. South African Journal of Higher Education 30, 2: 514 - 531.

Roux, C.D., J. Smith, R. Ferguson, R. Small, P. du Preez \& J. Jarvis 2006. Understanding Human Rights through Different Belief Systems: Intercultural and Interreligious Dialogue. Research Report: South African Netherlands Project on Alternative Developments (South Africa Netherlands Research Program on Alternatives in Development).

Samaras, A.P., M.A. Hicks \& J. Garvey Berger 2007. Self-Study through Personal History. In Loughran J., M.L. Hamilton, V.K. LaBoskey \& T.L. 
Russell (eds.): International Handbook of Self-Study of Teaching and Teacher Education Practices. New York: Springer.

Samuel, M. \& D. Stephens 2000. Critical Dialogues with Self: Developing Teacher Identities and Roles - A Case Study of South African Student Teachers. International Journal of Educational Research 33: 475 - 491. Available at:

https://doi.org/10.1016/S0883-0355(00)00030-6

Stengel, B.S. \& L. Weems 2010. Questioning Safe Space: An Introduction. Studies in Philosophy of Education 29: 505-507. Available at: https://doi.org/10.1007/s11217-010-9205-8

Janet Jarvis School of Education University of KwaZulu-Natal jarvisj@ukzn.ac.za 